\title{
Effects of different concentrations of passion fruit peel (Passiflora edulis) on the glicemic control in diabetic rat
}

\author{
Estudo dos efeitos de diferentes concentrações de casca de maracujá (Passiflora edulis) \\ no controle da glicemia de ratos diabéticos
}

\author{
Jocelem Mastrodi SALGADO ${ }^{1 *}$, Talita Aparecida Dias BOMBARDE ${ }^{1}$, Débora Niero MANSI ${ }^{1}$, \\ Sonia Maria de Stefano PIEDADE ${ }^{2}$, Laura Maria Molina MELETTI ${ }^{3}$
}

\begin{abstract}
Diabetes mellitus, an endocrine disorder, is the major cause of morbidity in developing countries, and it is considered the fourth leading cause of death worldwide. The conventional therapy for diabetes is insulin treatment. The peel of the Passion fruit is rich in fiber and prevents the absorption of carbohydrates, and thus can control and reduce the blood sugar rate. The objective of this study was to analyze the effect of the passion fruit peel flour on the glicemia of diabetic rats, as well as to study the probable action mechanisms. Wistar rats were used in the experiment and were offered the flours of the passion fruit peel in three concentrations: 5, 10, and 15\%, and a casein diet as control. The most significant effect on the reduction of the glicemic rate was obtained with the $5 \%$ diet. The best values of hepatic glycogen were found in the 5 and $10 \%$ diets. The results of this study suggest that the $5 \%$ passion fruit flour diet was the one that provided the best reduction of blood glucose levels (59\%) and the higher increase of the hepatic glycogen level (71\%). The conversion of blood glucose into hepatic glycogen was considered the probable action mechanism involved.

Keywords: hyperglycemia; diets; passion fruit; diabetes; rats.
\end{abstract}

\section{Resumo}

Diabetes melittus, uma desordem endócrina, é a maior causa de morbidade em países em desenvolvimento e é considerada a quarta causa de mortes no mundo. A terapia convencional para diabetes é o tratamento com insulina. A casca do maracujá é um material rico em fibras, e impede a absorção de carboidratos, podendo, dessa forma, controlar e reduzir a taxa de açúcar no sangue. O objetivo deste estudo foi analisar o efeito dessa farinha na glicemia de ratos diabéticos, bem como estudar os prováveis mecanismos de ação. Foram empregados ratos Wistar, aos quais foram oferecidas dietas balanceadas contendo farinhas da casca de maracujá em três concentrações, 5, 10 e 15\%, e tendo como controle uma dieta com caseína. A dieta que mostrou maior efeito significativo sobre o controle do diabetes foi a de 5\%, proporcionando uma redução de cerca de $60 \%$ da glicemia dos animais desse grupo e um aumento de $71 \%$ do glicogênio hepático. A conversão de glicose sanguínea em glicogênio hepático foi considerada um dos prováveis mecanismos de ação envolvidos.

Palavras-chave: hiperglicemia; dieta; maracujá; diabetes; ratos.

\section{Introduction}

Diabetes Mellitus, an endocrine disorder characterized by hyperglycemia and impaired insulin secretion, results from defects in insulin secretion or insulin action disorder or in both. It is the major cause of morbidity in developing countries (RAVI; RAJASEKARAN; SUBRAMANIAN, 2005). Nowadays, it is considered the fourth leading cause of death worldwide. The public affected by diabetes corresponds to approximately $3 \%$ of the world's population.

According to the World Health Organization (WHO), diabetes is expected to increase in the next 10 years thus it is considered a serious public health problem (CARRION; KATO; MOURÃO, 2002).

According to McIntyre (2001), this fact occurs mainly due to changes in lifestyle such as inadequate food intake and sedentary lifestyle resulting in the development of other diseases such as heart disease and obesity among other risk factors.

The genetic predisposition and lifestyle are related to the high rate of occurrence of non-insulin-dependent diabetes mellitus. The contemporary style of life characterized by low physical activity and diets rich in energy, such as carbohydrates and lipids, results in an increase in the levels of glucose in the tissues sensitive to insulin and an exacerbated resistance to this substance (DE PAULA, 2002).

The conventional therapy for diabetes Type I includes exogenous insulin, and diabetes Type II includes hypoglycemic agents. Nevertheless, diet is the best form of prevention. A research conducted in Australia and in the United States indicated that, respectively, 48.5 and $34 \%$ of the population

Recebido para publicação em 13/10/2008

Aceito para publicação em 28/10/2008 (003849)

${ }^{1}$ Departamento de Agroindustria, Alimentos e Nutrição/Nutrição Humana e Alimentos, Escola Superior de Agricultura "Luiz de Queiróz", Universidade de São Paulo - USP, CEP 13418900, Piracicaba - SP, Brasil, E-mail: jmsalgad@esalq.usp.br

2 Departamento de Ciências Exatas, Escola Superior de Agricultura "Luiz de Queiroz" - ESALQ, Piracicaba - SP, Brasil

${ }^{3}$ Centro de Pesquisa e Desenvolvimento de Recursos Genéticos Vegetais, Instituto Agronômico de Campinas - IAC, Campinas - SP, Brasil

${ }^{*}$ A quem a correspondência deve ser enviada 
use non-conventional therapies for the treatment of diseases, including medicinal herbs. In Brazil, it is clear that the treatment of diseases with the infusion of plants and cooking is a common practice despite the lack of statistical data on the subject (PEPATO et al., 2005).

Recent recommendations suggest that the consumption of grains, fruits, and vegetables should be increased to prevent or treat these chronic diseases. Among the possible components of these foods that may have hypoglycemic actions are protein, fibers, and some compounds called antinutrients, such as phytic acid, tannins, lecithins, and inhibitors of enzymes and saponins (COMMITTEE ON DIET AND HEALTH, 1989).

Some studies reported that the consumption of dietary fiber may reduce the risk of disease in populations, especially the prevention of cardiovascular and gastrointestinal diseases, colon cancer, hyperlipidemia, diabetes, and obesity among others (CHAU; HUANG, 2004).

Fibers have physiological effects related to laxation, increase the fecal cake, and reduce cholesterol and blood glucose levels due to their solubility in water (CERQUEIRA et al., 2008).

Several studies showed a protective effect of fibers on the development of insulin resistance and type 2 diabetes (SALMERON, 1997a, b; MEYER et al., 2000; PEREIRA et al., 2002).

In another study, Nandini, Sambaiah and Salimath (2000) found the greatest effect in reducing levels of glucose in the blood of diabetic rats with diet enriched with soluble fiber (guar gum). Those same fibers showed a significant effect of reducing blood glucose and insulin resistance, however, their impact on the risk of developing type 2 diabetes was not clearly defined (CHAMP et al., 2003).

Results showed that diets enriched with the flour of eggplant peel decreased blood glucose levels in diabetic animals. These results indicated that the soluble pectin in the diet contributed to the reduction in the glucose rate of these animals (DERIVI et al., 2002).

Another study, with a diet rich in fiber, also showed beneficial effects on the systolic blood pressure and levels of lipids in the blood suggesting a higher intake of fiber to prevent disease complications (JUE et al., 2004).

However, Laerke et al. (2007), on a trial with diabetic rats using potato pulp and soluble fiber, found no significant results in reducing blood glucose levels of cholesterol or plasma.

According to Córdova et al. (2005), some studies have shown the functional properties of the passion fruit peel, especially those related to the content and type of fiber. Due to these characteristics and functional properties, passion fruit has no longer been considered an industrial waste since it can be used in the development of new products.

The peel of passion fruit is rich in fiber, minerals, and especially pectin. Pectin is a fraction of soluble fiber in the gastrointestinal tract that forms a gel preventing the absorption of some nutrients. In the case of diabetes, it prevents the absorption of carbohydrates and can thus control and reduce the blood sugar rate (SACHS, 2002).

The purpose of this study was to determine the chemical composition and the concentration of antinutrients compounds, and also to evaluate the effect of different concentrations of the passion fruit peel on the blood glucose levels in diabetic rats.

\section{Materials and methods}

The chemical analysis and biological experiment were conducted at the Laboratory of Bromatology and Experimental Nutrition of the Agri-food Industry, Food and Nutrition Department, Luiz de Queiroz College of Agriculture (ESALQ/ USP).

The passion fruits investigated in this experiment were the IAC-275 yellow variety from the Agronomic Institute of Campinas (IAC).

\subsection{Material processing}

The fruits were cleaned out and only the peel was used for the production of the flour. The peel of the fruit was rinsed with distilled water, placed in trays, and dried in a circulating forced air incubator at 55 and $60^{\circ} \mathrm{C}$ for 48 hours. The dry peels were ground to a fine powder using a blender (Tecnal T345, Piracicaba - SP, Brazil) and stored in clear polyethylene bags at $10{ }^{\circ} \mathrm{C}$ prior to use.

\subsection{Chemical analysis}

The chemical analysis of the dry matter, total protein, ether extract, and ash were conducted with three replicates for each sample according to AOAC (ASSOCIATION..., 1975). The fiber content was determined through a method described in the literature (ASP et al., 1983), which used enzymes such as $\alpha$-amylase to hydrolyze starch and pepsin followed by pancreatin to break down proteins.

The minerals were determined according to the methodology described by Sarruge and Haag (1974).

\subsection{Antinutritional factors}

The concentration of tannins was determined through the protocol described by Price, Hagerman and Butler (1980); the standard curve was drawn using catechin and the results were expressed in $\mathrm{mEq}$ of catechin.

The total polyphenols were determined by the method proposed by Swain and Hillis (1959) using the reagent FolinCiocalteau.

\subsection{Preparation of diets}

The diets (Table 1) were prepared in accordance to Reeves, Nielsen and Fahey Junior (1993) and contained 15\% of protein each, and were divided into normal and diabetic control (casein) and three tests (casein + flour of passion fruit peel) in three different concentrations: 5,10 , and $15 \%$. 


\subsection{Biological experiment}

A total of 48 male Wistar rats (Rattus norvegicus), weighing between 200 to $220 \mathrm{~g}$, were selected for the biological assay.

In the beginning of the experiment, the animals were anesthetized with halothane, after a 24-hour fast for the induction of diabetes, with an injection of Alloxan monohydrate (4 mg. $\mathrm{kg}^{-1}$ body weight, dissolved in saline solution) in the dorsal vein of the penis. The dose was enough to cause diabetes of moderate intensity, according to Lazarow and Palayes (1946). The development of diabetes was controlled the daily by determining the level of glucose in urine using a glucose testtape (Glukotest) which allowed a diagnosis in animals that were kept alive. Eight animals were selected for initial sacrifice, after fasting for 12 hours, for blood collection through heart puncture. The blood sample was called time 0 (T0), and the liver was also collected for further analysis.

The remaining 40 animals were divided into 5 groups of 8 animals each and maintained in individual cages at room temperature (between 22 and $23^{\circ} \mathrm{C}$ ) with daily cycle consisting of 12 hours of light and 12 hours of darkness.

During the experiment, which lasted 30 days, they were fed the 5 diets and water was provided "ad libitum". Feed consumption and the animals' weight were recorded weekly. After thirty days of the experiment, new samples of blood were collected.

\subsection{Biological analysis}

The animals were sacrificed for blood and liver collection, after fasting for 12 hours, using halothane as anesthetic. For the blood glucose analysis, the blood was collected and immediately transferred into a test strip and checked using a blood glucose monitoring system (Accu-Chek). For the analysis of glycogen in liver, the method proposed by Hassid and Abraham (1957) was used.

\subsection{Statistical analysis}

The experimental design was performed randomly, according to the methodology described by Pimentel Gomes (2000), with 5 groups of 8 animals each and 5 treatments. The F test was applied for the variance analysis and the Tukey test was used to identify the statistic differences between the means.

\section{Results and discussion}

\subsection{Chemical analysis}

Analyzing the data in Table 2, it seems that the peel of the passion fruit has low levels of protein and ether extract, but these values were higher than those found by Oliveira et al. (2002), and probably this difference may be linked to the variety of the fruit studied.
The amount of soluble and insoluble fibers in the peel of the fruit deserves attention, which has also been mentioned by Bueno, Castilho e Costa (2005) and Córdova et al. (2005), who found similar levels.

The passion fruit peel showed a significant content of $\mathrm{Fe}$, $\mathrm{K}, \mathrm{Zn}$, and $\mathrm{Mn}$ (Table 3).These micro-nutrients are important for the metabolism, so the peel of the passion fruit can be considered an alternative source for the intake of these minerals. In addition, it represents a potential for new food products such as cereals and juices that can be fortified with this flour (CÓRDOVA et al., 2005).

Table 1. Composition of control and test diets supplemented with flour of passion fruit peel (PFPF).

\begin{tabular}{lcccc}
\hline \multicolumn{1}{c}{ Components } & Control & $5 \%$ & $10 \%$ & $15 \%$ \\
\hline Caseín $^{1}$ & 15.00 & 15.00 & 15.00 & 15.00 \\
Peel $5 \%^{7}$ & - & 5.00 & - & - \\
Peel $10 \%^{7}$ & - & - & 10.00 & - \\
Peel $15 \%^{7}$ & - & - & - & 15.00 \\
Soybean Oil $^{3}$ & 3.50 & 3.50 & 3.50 & 3.50 \\
Mineral Mixture $^{2}$ & 1.00 & 1.00 & 1.00 & 1.00 \\
Vitamin Mixture $^{2}$ & 0.25 & 0.25 & 0.25 & 0.25 \\
$\propto$ Cystine $^{4}$ & 0.30 & 0.30 & 0.30 & 0.30 \\
Terti Butil Hidroquinone $^{5}$ & 0.0014 & 0.0014 & 0.0014 & 0.0014 \\
Corn Starch $^{6}$ & \multicolumn{4}{c}{ Complete to $100 \%$} \\
\hline
\end{tabular}

${ }^{1}$ Synth; ${ }^{2}$ Reeves, Nielsen and Fahey Junior(1993); ${ }^{3}$ Lisa $^{\circledR} ;{ }^{4}$ Synth; ${ }^{5}$ Sigma; ${ }^{6}$ Maizena ${ }^{\circledR}$, ${ }^{7} \mathrm{IAC}-275$.

Table 2. Results of chemical analysis of the passion fruit peel used in the diets (g. $100 \mathrm{~g}^{-1}$ of dry matter).

\begin{tabular}{lc}
\hline Analysis & Result \\
\hline Humidity & 6.96 \\
Ether extract & 0.74 \\
Ash & 8.30 \\
Protein & 9.8 \\
Insoluble fiber & 54.27 \\
Soluble fiber & 3.49 \\
\hline
\end{tabular}

Table 3. Levels of minerals found in the passion fruit peel used in the diet.

\begin{tabular}{lc}
\hline Minerals & $\mathrm{g} \cdot \mathrm{Kg}^{-1}$ \\
\hline Calcium & 3.30 \\
Phosphorus & 1.51 \\
Potassium & 33.66 \\
Magnesium & 0.80 \\
Sulfur & 1.06 \\
Sodium & 2.81 \\
& $\mathrm{mg} \cdot \mathrm{Kg}^{-1}$ \\
Copper & 1.33 \\
Iron & 41.10 \\
Zinc & 11.60 \\
Manganese & 17.45 \\
\hline
\end{tabular}




\subsection{Antinutritional factors}

The antinutritional compounds (Table 4) found in the peel of the passion fruit can be of great importance because, depending on the quantities, they can influence the decrease of blood glucose.

According to the Committee on Diet and Health (1989), antinutrients such as phenolic compounds can prevent or treat chronic diseases, and the amount found in the peel of the passion fruit can have particular importance in the effect on the blood glucose of the diabetic rats.

\subsection{Biological analysis}

A significant statistical difference was observed for dietary consumption indicating lower consumption for the normal control group. However, in the diabetic control group and test groups, there was high consumption rate (Figure 1), probably due to glucose deprivation thus providing higher consumption of the diet (NANDINI; SAMBAIAH; SALIMATH, 2000).

The animals showed statistical differences in weight gain (Figure 2). The diabetic group showed no significant weight gain corroborating with Nandini, Sambaiah and Salimath (2000), who observed small weight gain in animals under hyperphagic conditions. However, the group that consumed $15 \%$ of PFPF did not show a high weight gain probably due to the high concentration of fibers in the diet.

Analyzing Figure 3 , it can be observed that the test diet with $5 \%$ of the flour of the passion fruit peel reduced the blood glucose

Table 4. Antinutritional (mg.g ${ }^{-1}$ of fresh matter) found in the peel of the passion fruit.

\begin{tabular}{cc}
\hline Antinutricional & Result \\
\hline Tannin & 0.17 \\
Phenolic compounds & 4.20 \\
\hline
\end{tabular}

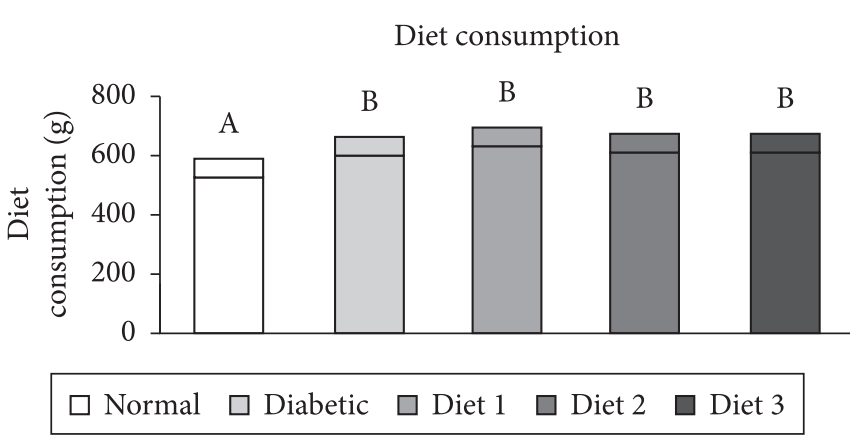

Figure 1. Total dietary consumption ( $\mathrm{g}$ ) by diabetic male Wistar rats treated with passion fruit peel flour during 30 days of experiment. ${ }^{*}$ ) Values of 8 animals, where: Normal $=15 \%$ casein diet; Diabetic $=15 \%$ casein diet; Diet $1=5 \%$ of PFPF; Diet $2=10 \%$ of PFPF; Diet $3=15 \%$ of PFPF. Averages with different letters in the graph differ statically at the level of $5 \%$. by $59 \%$ in diabetic rats reaching the normal glycemic amount (112.6 mg.dL $\left.\mathrm{dL}^{-1}\right)$.

It is likely that the mechanisms of action that helped to reduce the blood glucose levels were the transformation of blood glucose into liver glycogen, which maintained normal levels of glucose in the bloodstream, as well as the presence of soluble fiber, tannins, and phenolic compounds.

The presence of soluble fiber (pectin) found in fruits, mainly in the peel, can beneficially influence the diabetic patient, and according to Del-Vechio et al. (2005) these fibers reduce blood glucose. The benefits attributed to the fibers are the properties to increase the intestinal transit time, lower gastric emptying,

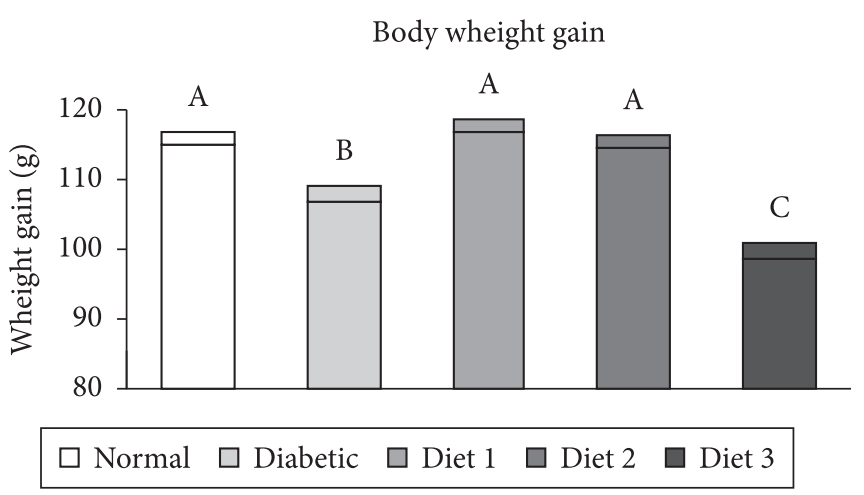

Figure 2. Total body weight gains (g) of diabetic male Wistar rats treated with passion fruit peel flour during 30 days of experiment. $\left({ }^{*}\right)$ Values of 8 animals, where: Normal $=15 \%$ casein diet; Diabetic $=15 \%$ casein diet; Diet $1=5 \%$ of PFPF; Diet $2=10 \%$ of PFPF; Diet $3=15 \%$ of PFPF. Averages with different letters in the graph differ statically at the level of $5 \%$

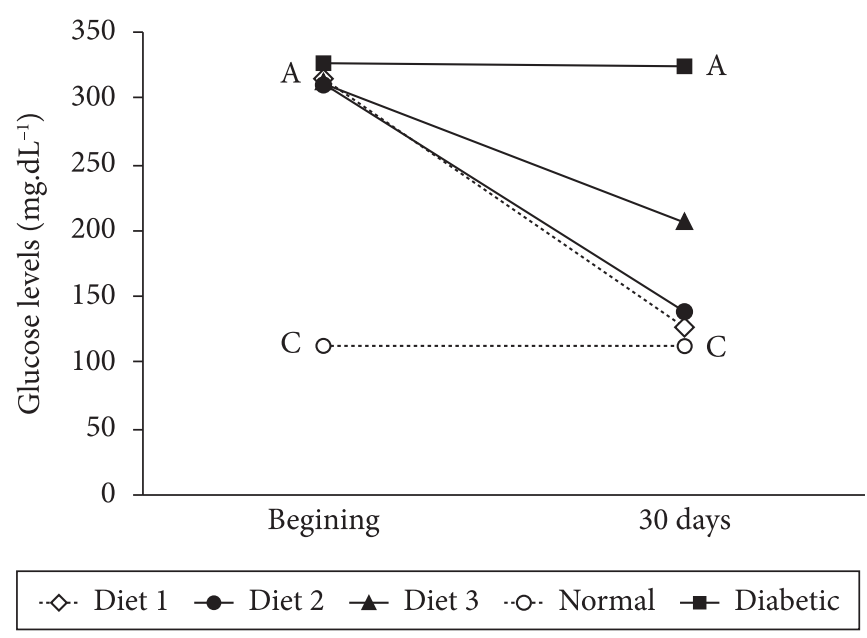

Figure 3. Levels of plasma glucose $\left(\mathrm{mg} . \mathrm{dL}^{-1}\right)$ in diabetic male Wistar rats treated with passion fruit peel flour during 30 days of experiment. $\left({ }^{*}\right)$ Values of 8 animals, where: Normal $=15 \%$ casein diet; Diabetic $=15 \%$ casein diet; Diet $1=5 \%$ of PFPF; Diet $2=10 \%$ of PFPF; Diet $3=15 \%$ of PFPF. Averages with different letters in the graph differ statically at the level of $5 \%$. 
delay absorption of glucose by slowing access to the absorptive epithelium, and hence to reduce postprandial glycaemia. In addition, the fibers with the highest level of viscosity such as soluble fibers are known for providing slower absorption of sugar in the intestine by interacting with intestinal enzymes (NANDINI; SAMBAIAH; SALIMATH, 2000).

Figure 4 shows the values of hepatic glycogen after 30 days of experiment.

The results of hepatic glycogen showed a significant increase in the diabetic rats fed the flour of the passion fruit peel. The values of liver glycogen for the $5 \%$ of PFPF group were almost equal to the values of the normal rats. One possible explanation for these results is that in the diabetic control group, the insulin insufficiency of the animals affected the glucose capture in peripheral tissues sensitive to the hormone thus accumulating the glucose in the extracellular liquid. Consequently, the synthesis of glycogen decreased, and probably its degradation was stimulated as a source of energy for the cell reflecting the significant reduction in glycogen content.

The presence of the passion fruit peel flour in the diet reduced the digestion and absorption of carbohydrates and increased the sensitivity of muscle and adipose tissue to insulin remaining allowing greater gluconeogenesis (production of liver glycogen), thereby contributing to the reduction of hyperglycemia of these animals (SACHS, 2002).

It is interesting to note that these positive results, both for glucose and hepatic glycogen, were not directly proportional to the increase in the concentration of the passion fruit peel flour in the diet. This study showed that under concentrations higher than $10 \%$, the consumption of the peel did not have the desired physiological effect.

Hepatic glycogen

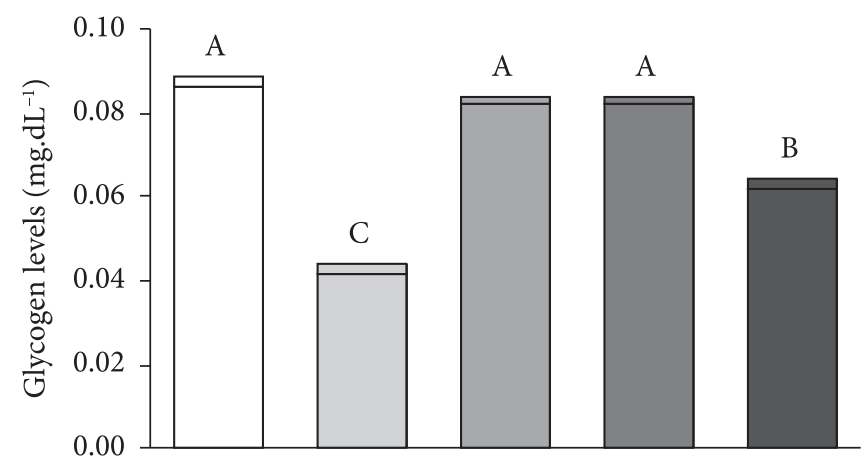

$\square$ Normal $\square$ Diabetic $\square$ Diet $1 \square$ Diet $2 \square$ Diet 3

Figure 4. Levels of hepatic glycogen $\left(\mathrm{mg}_{\mathrm{dL}} \mathrm{dL}^{-1}\right)$ in diabetic male Wistar rats treated with passion fruit peel flour during 30 days of experiment. ${ }^{*}$ ) Values of 8 animals, where: Normal $=15 \%$ casein diet; Diabetic $=15 \%$ casein diet; Diet $1=5 \%$ of PFPF; Diet $2=10 \%$ of PFPF; Diet $3=15 \%$ of PFPF. Averages with different letters in the graph differ statically at the level of $5 \%$.

\section{Conclusion}

The results of this study showed that the passion fruit peel affects the metabolism of carbohydrates, and can positively influence the metabolic control of diabetes by preventing or delaying complications associated with this disease.

\section{References}

ASP, N. G. et al. Rapid enzimatic assay in insoluble and soluble dietary fiber. Journal of Agricultural and Food Chemistry, v. 31, n. 3, p. 476-482, 1983.

ASSOCIATION OF OFFICIAL ANALYTICAL CHEMISTS. AOAC Official Methods of Analysis. 15. ed. Washington, D.C., USA, 1975.

BUENO, N. R.; CASTILHO, R. C.; COSTA, R. B. Medicinal plants used by the Kaiowá and Guarani indigenous populations in the Caarapó Reserve, Mato Grosso do Sul, Brazil. Acta Botânica Brasílica, v. 19, n. 1, p. 39-44, 2005.

CARRION, R. C. E.; KATO, E. T. M.; MOURÃO, K. S. M. Contribuição ao estudo farmacognóstico da insulina vegetal. Revista Brasileira de Ciências Farmacêuticas, v. 38, Supl. 1, p. 122, 2002.

CERQUEIRA, P. M. et al. Efeito da farinha de semente de abóbora (Cucúrbita máxima, L.) sobre o metabolismo glicídico e lipídico em ratos. Revista de Nutrição, v. 21, n. 2, p. 129-36, 2008.

CHAMP, M. et al. Advances in dietary fibre characterisation. 1. definition of dietary fibre, physiological relevance, health benefits and analytical aspects. Nutrition Research Reviews, Cambridge, v. 16, p. 71-82, 2003.

CHAU, C. F; HUANG, Y. L. Characterization of passion fruit seed fibres: a potential fibre source. Food Chemistry, v. 85, p. 189-194, 2004.

COMMitTeE ON DIET AND HEALTH. Diet and Health. Implications for reducing chronic disease risk. National Academy Press, Washington, D.C., 1989.

CÓRDOVA, K. R. V. et al. Características físicas e químicas da casca do maracujá amarelo (Passiflora edulis Flavicarpa Degener) obtida por secagem. Boletim CEPPA, v. 23, n. 2, p. 221-230, 2005.

DE PAULA, A. C. C. F. F. Carboidratos, flavonóides e atividade antidiabética de Rhynchelytrum repens (Willd.) C. E. Hubb, Capim-favorito (poaceae). 2002. 170 f. Tese (Doutorado)Universidade de São Paulo, São Paulo, 2002.

DEL-VECHIO, G. et al. Efeito do tratamento térmico em sementes de abóboras (Cucurbita spp) sobre os níveis de fatores antinutricionais e/ou tóxicos. Ciência Agrotecnológica, v. 29, n. 2, p. 369-76, 2005.

DERIVI, S. C. N. et al. Efeito hipoglicêmico de rações à base de berinjela (Solanum melongena, L.) em ratos. Ciência e Tecnologia de Alimentos, v. 22, n. 2, 2002.

HASSID, W. Z.; ABRAHAM, S. Chemical procedures for analisys of polyssacarides. Methods Enzymology, v. 3, p. 34-50, 1957.

JUE, L. et al. Effects of fiber intake on the blood pressure, lipids, and heart rate in Goto Kakizaki rats. Nutrition, v. 20, n. 11-12, p. 1003-7, 2004.

LAERKE, H. N. et al. Soluble fiber extracted from potato pulp is highly fermentable but has no effect on risk markers of diabetes and cardiovascular disease in Goto-Kakizaki rats. Nutrition Research, v. 27, n. 3, p. 152-160, 2007. 
LAZAROW, A.; PALAY, S. L. The production and course of alloxan diabetes in the rat. The Journal of Laboratory Clinical of Medicine, v. 31, p. 1004-1015, 1946.

MCINTYRE, A. Bebidas que curam. São Paulo: Manole, 2001.

MEYER, K. A. et al. Carbohydrates, dietary fiber, and incident type 2 diabetes in older women. American Journal of Clinical Nutrition, v. 71, p. 921-930, 2000.

NANDINI, C. D.; SAMBAIAH, K.; SALIMATH, P. V. Effect of dietary fibre on intestinal and renal disaccharidases in diabetic rats. Nutrition Research, v. 20, n. 9, p. 1301-07, 2000.

OLIVEIRA, L. F. et al. Aproveitamento alternativo da casca do maracujá-amarelo (Passiflora edulis F. Flavicarpa) para produção de doce em calda. Ciência e Tecnologia de Alimentos, v. 22, n. 3 , 2002.

PEPATO, M. T. et al. Fruit of the jambolan tree (Eugenia jambolana Lamb.) and experimental diabetes. Journal of Ethnopharmacology, v. 96, p. 43-48, 2005.

PEREIRA, M. A. et al. Effect of whole grains and insulin sensitivity in overweight hyperinsulinemic adults. American Journal of Clinical Nutrition, v. 75, p. 848-855, 2002.

PIMENTEL GOMES, F. Curso de estatística experimental. 14. ed. São Paulo: Nobel, 2000.
PRICE, M. L.; HAGERMAN, A. E.; BUTLER, L. G. Tanin Content of Cowpeas, Chickpeas, Pigeon Peas and Mung Beans. Journal of Agricultural and Food Chemistry, v. 28, n. 2, p. 459-461, 1980.

RAVI, K.; RAJASEKARAN, S.; SUBRAMANIAN, S. Antihyperlipidemic effect of Eugenia jambolana seed kernel on streptozotocin-induced diabetes in rats. Food and Chemical Toxicology, v. 43, p. 1433-1439, 2005.

REEVES, P. H.; NIELSEN, F.H.; FAHEY JUNIOR, G. C. AIN - 93 Purified diets of laboratory rodents: final report of the American Institute of Nutrition. Ad Hoc writing Commitee on the reformulation of AIN-76 rodent diet. Journal of Nutrition, v. 123, p. 1939-1951, 1993.

SACHS, A. Diabetes mellitus. In: Cuppari, L. Nutrição: nutrição clínica no adulto, 2002. p.151-165.

SALMERON, J. et al. Dietary fiber, glicemic load, and risk of NIDDM in men. Diabetes care, v. 20, p. 545-550, 1997a.

SALMERON, J. et al. Dietary fiber, glicemic load, and risk of noninsulin-dependet diabetes mellitus in women. Jama, v. 277, p. 472477, 1997b.

SARRUGE, J. R.; HAAG, H. P. Análises Químicas em Plantas. Piracicaba, ESALQ-USP, 1974.

SWAIN,T.; HILLIS,W. E. Journal of Sciences and Food Agriculture v. 10 , p. $63-68,1959$. 